[Cartografia]

\title{
CARTOGRAFIA SOCIAL DAS MULHERES DA COMUNIDADE RAPOSA/RIBEIRÃO RIBEIRÃO D'ANTA
}

\section{SOCIAL CARTOGRAPHY OF WOMEN IN THE RAPOSA/RIBEIRÃO D'ANTA COMMUNITY}

\author{
Valéria Pereira Santos ${ }^{1}$ \\ ${ }^{1}$ Comissão Pastoral da Terra (CPT) e Programa de Pós-Graduação em Demandas \\ Populares e Dinâmicas Regionais - Universidade Federal do Tocantins (UFT) \\ valria.sants@gmail.com
}

\begin{abstract}
Resumo: Este cartograma é um dos resultados da pesquisa "Mulheres e conflitos socioambientais: saberes e olhares da camponesas" sobre os impactos da soja na Serra do Centro, Campos Lindos/TO, defendia em 2019 no Programa de Pós-Graduação em Demandas Populares e Dinâmicas Regionais (PPGdire/UFT). O estudo buscou dar visibilidade às mulheres camponesas e seus modos de vida nas áreas de conflitos socioambientais. Além das violências intrínsecas ao modelo de sociedade patriarcal, as mulheres com liderança sofrem violências extremas, como assassinatos e a perda dos bens comuns, que são fontes de sustentação dos seus modos de vida. Na Serra do Centro, o conflito socioambiental chegou juntamente com os sojicultores do Projeto Agrícola Campos Lindos, em 1997; um grande projeto de interesses econômicos e políticos privado, com dimensão regional e nacional. Já são mais de vinte anos de conflito, e o território tradicional e os modos de vida das mulheres camponesas sofreram grandes transformações. Por isso, o objetivo do estudo foi identificar e refletir sobre os impactos socioambientais gerados pelo Projeto à vida das mulheres camponesas a partir dos seus olhares e compreensões. Para construir o enredo dessa história, foi realizado um mapeamento social dos saberes e olhares das camponesas da Raposa/Ribeirão D'anta, refletindo sobre as histórias de vida das mulheres, as relações de convivência com o ambiente, a inserção na organização política, social e familiar e o que essas mulheres defendem como desenvolvimento. Para compreender o espaço vivido pelas camponesas e as mudanças deste mesmo espaço, frente às transformações socioambientais ocorridas na Raposa/Ribeirão D'anta após a implantação das lavouras de soja, foi reproduzida cartograficamente a dinâmica do território, identificando as relações cotidianas das mulheres no espaço vivido.
\end{abstract}

Abstract: This cartogram is one of the results of the research "Women and socio-environmental conflicts: peasants' knowledge and views" on soybean 
impacts in Serra do Centro, Campos Lindos/TO, defended in 2019 in the Postgraduate Program in Popular Demands and Regional Dynamics. The study sought to give visibility to peasant women and their ways of life in the areas of social and environmental conflicts. In addition to violence intrinsic to the patriarchal model of society, women with leadership suffer extreme violence, such as murder and the loss of the commons, which are sources of support for their livelihoods. In Serra do Centro the social and environmental conflict came together with the soy farmers of the Campos Lindos Agricultural Project in 1997; a large project of private economic and political interests, with regional and national dimension. It's been over twenty years of conflict, and the traditional territory and lifestyles of peasant women have undergone major transformations. Therefore, the objective of the study was to identify and reflect on the social and environmental impacts generated by the Project on the lives of peasant women from their perspectives and understandings. To build the plot of this story, a social mapping of the knowledge and views of the peasants of Raposa/Ribeirão D'anta was carried out, reflecting on women's life histories, relationships with the environment, insertion in the political, social organization, family, and what these women stand for as development. To understand the space lived by the peasants and the changes in this same space, in view of the social and environmental transformations that occurred in Raposa/Ribeirão D'anta after the implementation of soybean crops, the territory dynamics was mapped, identifying the daily relationships of women in the space where they live.

\section{Mapa social da Comunidade Raposa/Ribeirão D'anta}

A representação cartográfica na figura 1 evidencia o território, os espaços ocupados pelas mulheres e os desafios cotidiano tensionados pelos impactos das lavouras de soja. O exercício da construção do mapa, antecedido pelos exercícios das narrativas e da roda de conversa, possibilitou a elas se enxergaram no território, através das percepções e sofrimentos, e fortaleceu as relações de confiança no processo da pesquisa (Santos, 2019). 


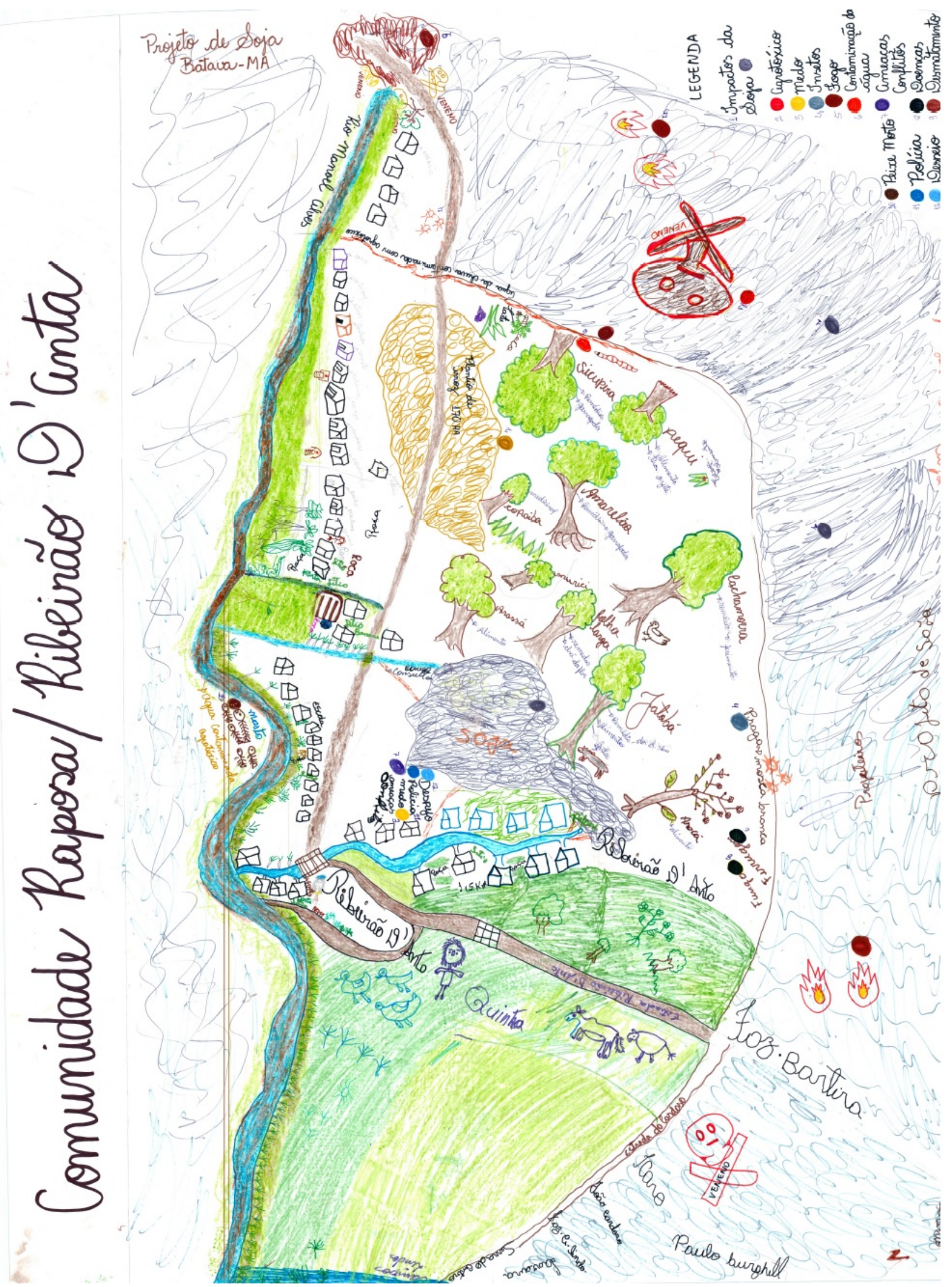

Figura 1: Mapa social do território da Raposa/Ribeirão D'anta Fonte: Santos e Branco (30/06/2018). 


\section{Referência}

Santos, V. P. (2019). Mulheres e conflitos socioambientais, saberes e olhares das camponesas sobre os impactos da soja na Serra do Centro, Campos Lindos/TO (Dissertação do Programa de Pós-Graduação Demandas Populares e Dinâmicas Regionais, Universidade Federal do Tocantins).

Submetido: 01/10/2019

Aprovado: 19/10/2019 